\title{
IMMUNOGLOBULIN G PROTEOLYTIC ACTIVITY OF ACTINOBACILLUS ACTINOMYCETEMCOMITANS
}

\author{
Fernanda Akemi Nakanishi'; Mario Julio Avila-Campos²; Nádia Hizuru Kamiji; Eiko Nakagawa Itano ${ }^{4 *}$ \\ ${ }^{1}$ Coordenação de Aperfeiçoamento de Pessoal de Nível Superior - CAPES, São Paulo, SP, Brasil; ${ }^{2}$ Departamento de \\ Microbiologia, Instituto de Ciências Biomédicas, Universidade de São Paulo, São Paulo, SP, Brasil; ${ }^{3}$ IC-CPG, Universidade \\ Estadual de Londrina, Londrina, PR, Brasil; ${ }^{4}$ Departamento de Ciências Patológicas, Centro de Ciências Biológicas, \\ Universidade Estadual de Londrina, PR, Brasil
}

Submitted: December 20, 2004; Returned to authors for corrections: April 25, 2005; Approved: February 03 , 2006

\begin{abstract}
Actinobacillus actinomycetemcomitans produces a protease to human immunoglobulin $\mathrm{G}$ that is an important evasion mechanism. In this study, the proteolytic activity of A. actinomycetemcomitans strain ATCC 43718 on human immunoglobulin $\mathrm{G}$ associated with culture supernatant concentrations, the growth period and the period of incubation with immunoglobulin $\mathrm{G}$ were evaluated by an enzyme linked immunosorbent assay. The protease fraction was detected by Sephadex G 150 chromatography. The results showed that $A$. actinomycetemcomitans produced a protease to human immunoglobulin $\mathrm{G}$ in the culture supernatant, and the highest activity was achieved witen the concentration was $27.5 \mu \mathrm{g}$ protein $/ \mathrm{mL}$, after culturing for 72 hours and incubating with IgG for 24 hours. The molecular mass of the protease active fraction was from 43 to $150 \mathrm{kDa}$.
\end{abstract}

Key words: immunoglobulin G, Actinobacillus actinomycetemcomitans, ELISA, protease

\section{INTRODUCTION}

Actinobacillus actinomycetemcomitans is a Gramnegative coccobacillus, frequently associated with localized aggressive periodontitis [LAP] which is characterized by rapid and marked bone loss around the incisor and molar teeth $(1,9,14,20)$. This organism has been also associated with a variety of non-oral infectious diseases such as endocarditis, osteomyelitis, septicemia, pneumonia, arthritis and abscesses. It has been estimated that approximately $0.6 \%$ of infective endocarditis is caused by A. actinomycetemcomitans, and it has been detected in $18 \%$ of atherosclerotic plaque samples from patients (8).

A. actinomycetemcomitans produces several virulence factors, such as a leukotoxin belonging to the RTX family that destroys neutrophils and monocytes $(3,8,18,20)$, a cytolethal distending toxin (CDT) that causes arrest of the mammalian cell cycle in $\mathrm{G} 2$ and a chaperonin 60 with potent leukocyte-activating and bone resorbing activities (8). It has been shown that this bacteria also produces a protease to collagen type I and fibronectin characterized as serine or metallo protease with 50 $\mathrm{kDa}$ (19). The metallocollagenase produces multiple scissions in the collagen molecule, and seems able to degrade native Type I collagen, destroying the periodontal connective tissue (4). A. actinomycetemcomitans produces proteins inhibiting osteoblast proliferation and bone collagen synthesis, and a capsular-like polysaccharide that inhibits osteoblast proliferation by inducing apoptosis (8).

Moreover, A. actinomycetemcomitans produces a bacteriocin that plays an important ecological role in regulating the intra- and inter-specific oral microbiota $(6,10,11)$. Antibodies produced against these virulence factors may be beneficial to the host, but $A$. actinomycetemcomitans produces proteases that cleave immunoglobulins [Igs] (5) and factors that can inhibit Igs production by human B cells (15) and the lymphoproliferative response (17).

*Corresponding Author. Mailing address: Departamento de Ciências Patológicas, Centro de Ciências Biológicas, Campus Universitário, Universidade Estadual de Londrina. 86051-990, Londrina, PR, Brasil. Fax: (+5543) 3371-4207. E-mail: itanoeiko@ hotmail.com 
Considering the sparse data related to the Ig protease of $A$. actinomycetemcomitans, the aim of the present study was to partially characterize the protease produced by $A$. actinomycetemcomitans against human IgG.

\section{MATERIALS AND METHODS}

\section{Microorganism}

A. actinomycetemcomitans [ATCC 43718] serotype b was grow at $37^{\circ} \mathrm{C}$ for 24,48 and $72 \mathrm{~h}$ on brain heart infusion broth [BHI] [Biobrás, Montes Claros, MG, Brazil], supplemented with $0.5 \%$ yeast extract [Biobrás, Montes Claros, MG, Brazil] under microaerophilic conditions [candle jar] as described by AvilaCampos et al. (2). The organisms were harvested by centrifugation [1x] [Hitachi himac CR21, Japan] [10.000 x g, 20 $\left.\min , 4^{\circ} \mathrm{C}\right]$ and the supernatant protein concentrations were determined by Folin method, using bovine serum albumin as standard (12). All samples were adjusted to the same protein concentration $[880 \mathrm{mg} / \mathrm{mL}]$, and $1.0 \mathrm{~mL}$ aliquots were stored at $-80^{\circ} \mathrm{C}$ until use.

\section{Human IgG purification}

Human IgG was purified from serum in a Sepharose-protein G column [Sigma Chemical Co., St. Louis, MO, USA]. The IgG was eluted with $0.1 \mathrm{M}$ glycine- $\mathrm{HCl}, \mathrm{pH} 2.8$, and immediately neutralized with $2 \mathrm{M}$ Tris, $\mathrm{pH}$ 9.0. Fractions $[1.0 \mathrm{~mL}]$ were collected and read in a spectrophotometer at $280 \mathrm{~nm}$. The fractions with the highest absorbency were mixed. The resulting pool was dialysed against $0.15 \mathrm{M}$ phosphate-buffered saline [PBS], and the protein concentration was determined using the Folin phenol method (12).

\section{IgG proteolytic activity of $A$. actinomycetemcomitans} ATCC 43718

The IgG proteolytic activity of A. actinomycetemcomitans ATCC 43718 supernatants was performed according to Gregory et al. (5), with some modifications. Purified human IgG [250 ng well $\left.{ }^{-1}\right]$ was diluted in $0.1 \mathrm{M}$ carbonate buffer, $\mathrm{pH}$ 9.6, and 96-well flat polystyrene plates [Kartell S.P.A, Novigilio, Milan, Italy] were sensitized and incubated for $1 \mathrm{~h}$, at $37^{\circ} \mathrm{C}$ and overnight at $4^{\circ} \mathrm{C}$. The plates were washed 5 times with PBS- $0.05 \%$ Tween 20 [PBS-T], blocked with PBS-T-5\% skim milk [PBS-T-M] for $2 \mathrm{~h}$, at $37^{\circ} \mathrm{C}$, and then incubated with A. actinomycetemcomitans ATCC 43718 supernatants $[24,48$ and $72 \mathrm{~h}$ cultures] without dilutions and diluted 1/8,1/16, 1/32, 1/64,1/128, 1/256, 1/512, 1/1024 in a period of 4,6 e $24 \mathrm{~h}$ of incubation. The BHI medium [Biobrás, Montes Claros, MG, Brazil] was used as control. The plates were washed with PBS-T [5x] and incubated with anti-human IgG peroxidase-labeled diluted 1:4000 [Sigma Chemical Co., St. Louis, MO, USA], washed 5 times, and a substrate solution [5mg orthophenylenediamine - Sigma Chemical Co., St. Louis, MO, USA, $10 \mathrm{~mL}$ of $0.1 \mathrm{M}$ citrate buffer, $\mathrm{pH} 4.5$ and $5 \mu \mathrm{L} \mathrm{H}_{2} \mathrm{O}_{2}$ ]
[100 $\mu \mathrm{L}$ well $\left.{ }^{-1}\right]$ was added. The reaction was halted with $50 \mu \mathrm{L}$ of $4 \mathrm{~N} \mathrm{H}_{2} \mathrm{SO}_{4}$ and absorbency was read in a Titertek Multiskan EIA reader [Labsystems, Helsinki, Finland] at $492 \mathrm{~nm}$. The protease activity was determined in percentage of degradation, considering $100 \%$ non-degradation with BHI medium.

\section{Sephadex G-150 chromatography of A. actinomycetemcomitans ATCC 43718 supernatants}

A. actinomycetemcomitans ATCC 43718 supernatants [2 mL] were fractionated in a Sephadex G-150 [Sigma, St. Louis, Missouri, U.S.A.] column balanced with 0.15 M PBS pH 7.2. Fractions $[1.0 \mathrm{~mL}]$ were collected and read in a spectrophotometer at $280 \mathrm{~nm}$, and the active $\mathrm{IgG}$ protease fraction was determined by ELISA. For partial characterization, dextran blue [exclusion volume, more than $150 \mathrm{kDa}$ ] and $43 \mathrm{kDa}$ glycoprotein from Paracoccidioides brasiliensis were applied to the same column.

\section{Statistical analysis}

Data were analyzed statistically by using ANOVA F and Tukey's Test [variance analysis] and considered significant if the $\mathrm{P}$ value was lower than $0.05[\mathrm{p}<0.05]$.

\section{RESULTS}

\section{IgG proteolytic activity of A. actinomycetemcomitans ATCC 43718}

The mean value of three trials in triplicate of IgG proteolytic activity of A. actinomycetemcomitans ATCC 43718 supernatants determined in percentage of degradation was higher at $1 / 32$ dilution $[27.5 \mu \mathrm{g} / \mathrm{mL}]$ than pure and diluted by $1 / 8,1 / 16,1 / 64$, $1 / 128,1 / 256,1 / 512,1 / 1024[\mathrm{p}<0.05]$ and higher at $72 \mathrm{~h}$ than at 24 and $48 \mathrm{~h}$ of culture $[\mathrm{p}<0.05]$. In relation to $\operatorname{IgG}$ incubation time, in a $1 / 32$ dilution the higher activity was observed with $24 \mathrm{~h}$ of incubation [p<0.05] . However, in dilutions of 1/128, $1 /$ 256 and $1 / 512$ the highest activity was observed after $6 \mathrm{~h}$ of incubation [p<0.05] [Figs. 1 and 2].

\section{Analysis of IgG protease activity in A. actinomycetemcomitans ATCC 43718 fractions}

The results of Sephadex G-150 chromatography of $A$. actinomycetemcomitans ATCC 43718 supernatants fraction by ELISA showed IgG protease activity in fractions 13 to 17 [Fig. 3]. The dextran blue eluted in a fraction 9 and $43 \mathrm{kDa}$ glicoprotein in a fraction 19.

\section{DISCUSSION}

The human oral microbiota is complex and diverse. It is composed of more than 300 bacterial species (13). The IgG, IgM and $\operatorname{Ig} \mathrm{A}$ antibodies produced against several oral microorganisms have been detected in plasma and crevicular 


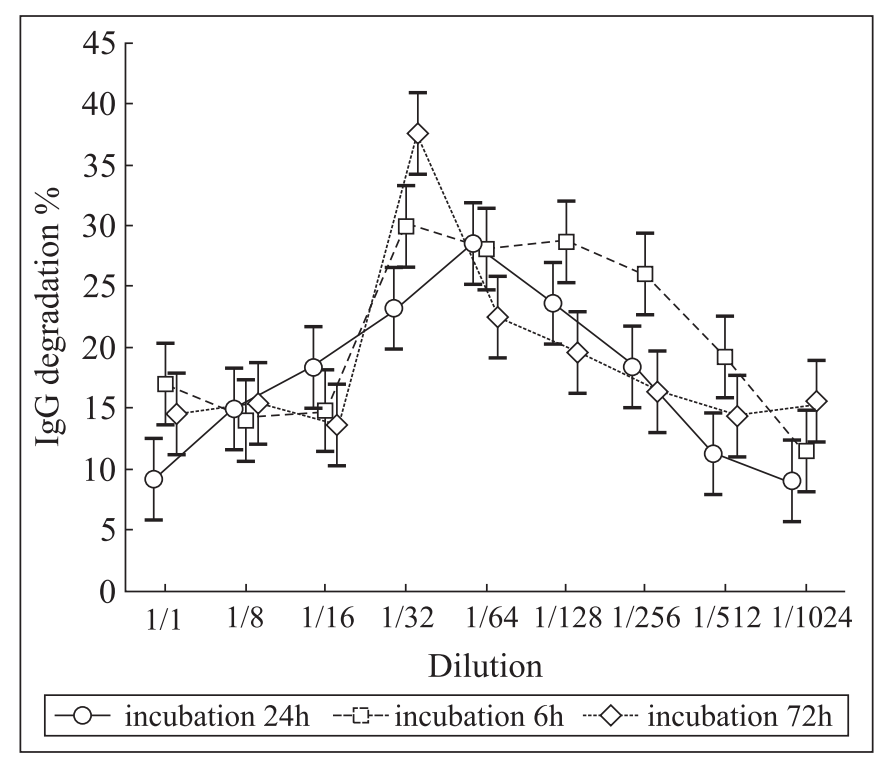

Figure 1. The mean value of three trials in triplicate of human $\mathrm{IgG}$ incubated for 4,6 and $24 \mathrm{~h}$ with pure, $1 / 8,1 / 16,1 / 32,1 / 64$, $1 / 128,1 / 256,1 / 512,1 / 1024$ diluted culture supernatant and then incubated with anti-human IgG peroxidase and the absorbancy read at $492 \mathrm{~nm}$ and the results determined in percentage of degradation, considering $100 \%$ non-degradation with BHI medium by ELISA.

$1 / 1,1 / 8,1 / 16 \times 1 / 32,1 / 64 \mathrm{p}<0.05$

$1 / 32,1 / 64 \times 1 / 128,1 / 256,1 / 512,1 / 1024 \mathrm{p}<0.05$;

$4 \mathrm{~h} \times 6 \mathrm{~h}=\mathrm{p}>0.05$;

$4 \mathrm{~h} \times 24 \mathrm{~h}[1 / 32]=\mathrm{p}<0.05$;

$6 \mathrm{~h} \times 24 \mathrm{~h}[1 / 32]=\mathrm{p}<0.05$.

fluid, even in heatthy individuals. These antibodies may influence the oral microbiota by interfering with adherence or by inhibiting bacterial metabolism. Moreover, the $\mathrm{IgG}$ antibodies may enhance phagocytosis and death of oral microorganisms through activation of the complement or opsonization (13). However, Ig can be degraded by proteases produced by several bacterial species that colonize mucosal and tooth surfaces (13), including periodontal pathogens (4). Gregory et al. (5) demonstrated the presence of proteolytic enzymes in the supernatant of cultures of A. actinomycetemcomitans, and that these enzymes can cleave $\operatorname{IgG}, \operatorname{Ig} \mathrm{A}$ and $\operatorname{IgM}$ in vitro.

This activity may be the factor which favors the growth of A. actinomycetemcomitans. Considering the bacteriocinogenic activity of A. actinomycetemcomitans (11), which can regulate intra- and interspecific microbiota, both of these virulence factors may play an important ecological role in the mouth.

Investigation of the factors that may modify the oral microbiota is important, considering the recent evidence suggesting that dental infection may be a predisposing factor

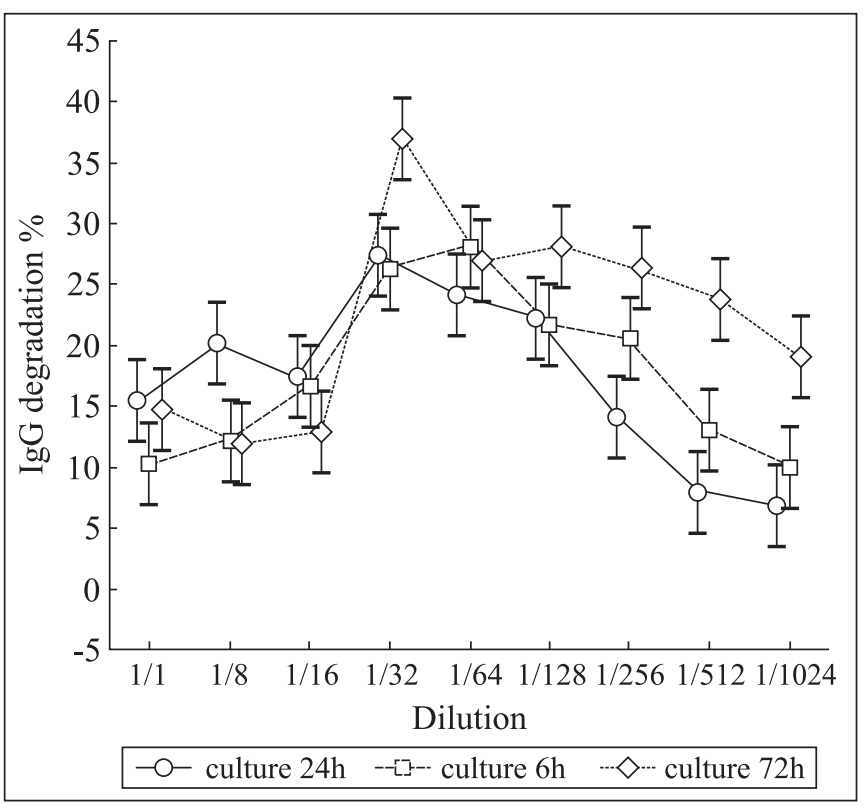

Figure 2. The mean value of three trials in triplicate of human IgG incubated with pure, 1/8, 1/16, 1/32, 1/64, 1/128, 1/256, $1 / 512,1 / 1024$ diluted supernatant of 24,48 and $72 \mathrm{~h}$ culture supernatant and then incubated with anti-human $\operatorname{IgG}$ peroxidase and the absorbency read at $492 \mathrm{~nm}$ and the results determined in percentage of degradation, considering $100 \%$ nondegradation with $\mathrm{BHI}$ medium by ELISA.

$72 \mathrm{~h} \times 24 \mathrm{~h}[1 / 32]=\mathrm{p}<0.05$;

$72 \mathrm{~h} \times 48 \mathrm{~h}[1 / 32]=\mathrm{p}<0.05$.

in systemic conditions such as coronary heart disease, diabetes and low birth weight (7).

In order to partially characterize the A. actinomycetemcomitans protease to IgG, supernatants of this organism were incubated with human IgG. The IgG degradation was revealed by using an anti-human $\operatorname{IgG}$ conjugated with peroxidase. The protease activity in A. actinomycetemcomitans strain ATCC $43718 \mathrm{IgG}$ associated with culture supernatant concentrations was dose-dependent; the highest activity was observed when supernatants were diluted 1/32 [27.5 $\mu \mathrm{g}$ protein $/ \mathrm{mL}]$. At high concentrations there was low activity, suggesting that some component not studied here may inhibit that activity. Additional studies are necessary to better understand the protease action.

The highest protease activity was observed in the 72 hour culture of the supernatant. This could be explained either by high enzyme production or by accumulation, which may be growth-time-dependent.

The protease activity was observed after 4, 6 and 24 hours of incubation with supernatant culture and human IgG. The highest protease activity in the $1 / 32$ supernatant dilution was observed for the 24 hour incubation. However, in dilutions of 1/128, 1/256 


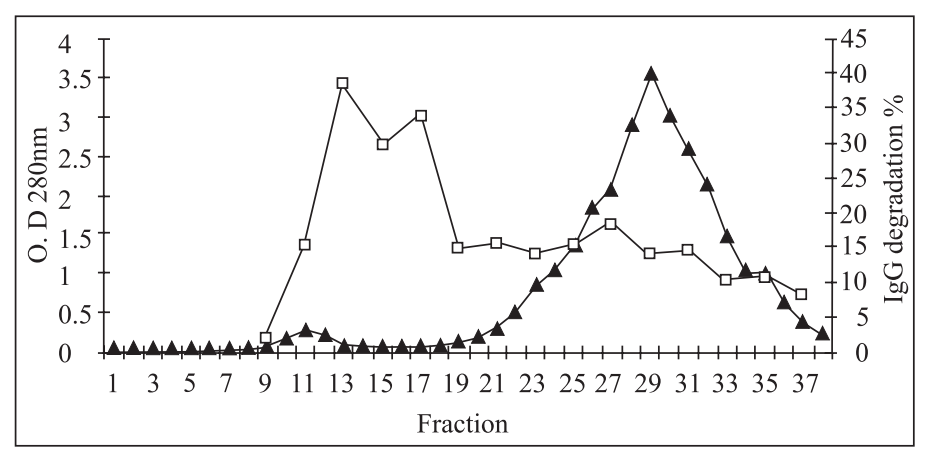

Figure 3. Spectrophotometric profile at $280 \mathrm{~nm}$ of fractions obtained from A. actinomycetemcomitans ATCC 43718 culture supernatants chromatography in Sephadex G-150 [- $\mathbf{\Delta -}]$ and IgG proteolytic activity by ELISA [- $\square-]$. The fractions $[1.0 \mathrm{~mL}]$ were collected with an automatic fraction collector, read in a spectrophotometer. The IgG proteolytic activity were determined by three trials in triplicate of human $\mathrm{IgG}$ incubated for $24 \mathrm{~h}$ with fraction sample [1/32] and then incubated with anti-human IgG peroxidase and the absorbency read at $492 \mathrm{~nm}$. The results of IgG proteolytic activity were determined in percentage of degradation, considering $100 \%$ non-degradation with BHI medium.

and $1 / 512$ the highest activity was observed, unexpectedly, after 6 hours of incubation. This result can be explained by the extensive IgG degradation after 24 hours, at these dilutions, and IgG conjugated with peroxidase binding in the ELISA plate, or by other variations including the supernatant culture period, or by some other factor. The use of purified IgG protease may eliminate the many components present in the culture supernatant that may influence the protease activity. This question will be the subject of future investigation.

In addition, to characterize the $A$. actinomycetemcomitans protease to $\mathrm{IgG}$, the culture supernatant was fractionated by gel filtration chromatography and the protease activity was determined by ELISA. IgG protease activity was detected in fractions 13 to 17 . The molecular masses [MM] of the components of these fractions were estimated as less than 150 $\mathrm{kDa}$ and more than $43 \mathrm{kDa}$, considering the later elution void volume $[150 \mathrm{kDa}]$ and prior to the reference $43 \mathrm{kDa}$ glycoprotein.

The protease activity observed in the five fractions may be due to the participation of proteases with different MMs or to the action of proteases at higher dilutions, as observed in this study. Gathering more precise data concerning the IgG protease MM requires further investigation.

In all of the culture supernatant concentrations, growth periods or incubation times investigated, the supernatant culture results were different from the BHI control, showing a protease activity in the supernatant, even in low degree [data not shown]. This A. actinomycetemcomitans IgG protease activity observed in vitro may also act in vivo. Smith and Taubman (16) reported that $\operatorname{IgG}$ in dental plaque extracts was extensively degraded as a Fc fragment and Gregory et al. (5) observed severe degradation of $\operatorname{IgG}$ and $\operatorname{IgA}$ with crevice gingival samples from patients with localized aggressive periodontitis.

The A. actinomycetemcomitans protease in periodontal tissue may destroy IgG after 4-6 hours of contact, based on the in vitro results. Considering that this activity was present even in high supernatant dilutions, it is possible that this enzyme may act externally by diffusion through saliva, periodontal tissue, mucosa or even blood. However, further studies are necessary to confirm this hypothesis.

We concluded that A. actinomycetemcomitans produces a protease against human immunoglobulin $\mathrm{G}$ with high activity in BHI supernatant cultures at $27.5 \mu \mathrm{g}$ protein $/ \mathrm{mL}$ concentration, after 72 hours growth and incubation with $\mathrm{IgG}$ for 24 hours. The molecular mass of the active fraction of protease is between approximately 43 and $150 \mathrm{kDa}$.

\section{ACKNOWLEDGEMENTS}

The authors thank Mari Sumigawa Kaminami and Nilson de Jesus Carlos for their technical assistance, Dr Édio Vizoni for statistical analysis and Janet W. Reid for her careful correction of the English text.

\section{RESUMO}

\section{Atividade proteolítica de Actinobacillus acitnomycetemcomitans sobre imunoglobulina G}

Actinobacillus actinomycetemcomitans produz protease ativa sobre imunoglobulina G humana, sendo um dos mecanismos importantes de escape do microrganismo. No presente trabalho, foi analisada a atividade proteolítica de sobrenadante de cultivo de A. actinomycetemcomitans ATCC 43718 sobre imunoglobulina $\mathrm{G}$ humana em função de concentração, tempo de cultivo do microrganismo e tempo de incubação com IgG, por ensaio imunoenzimático. Adicionalmente, foi determinada a fração com atividade de protease por meio de análise de eluatos de cromatografia em coluna de Sephadex G 150. Os resultados obtidos demonstraram que A. actinomycetemcomitans liberou protease ativa sobre imunoglobulina $\mathrm{G}$ humana em sobrenadante de cultivo, sendo a sua maior atividade evidenciada na concentração de 27,5 $\mu$ g proteína/mL, com tempo de cultivo de 72 horas e com 24 horas de incubação com IgG. A massa molecular da fração ativa de protease foi compreendida entre 43 a $150 \mathrm{kDa}$.

Palavras-chave: imunoglobulina G, Actinobacillus actinomycetemcomitans, ELISA, protease 


\section{REFERENCES}

1. Asikainen, S.; Jousimies-Somer, H.; Kanervo, A.; Summanen, P. Certain bacterial species and morphotypes in localized juvenile periodontitis and in matched controls. J. Periodontol., 58, 224230, 1987.

2. Avila-Campos, M.J.; Farias, L.M.; Carvalho, M.A.R.; Damasceno, C.A.V.; Cisalpino, E.O.; Costa, J.E. Aspectos ecológicos de Actinobacillus actinomycetemcomitans: aislamiento y caracterización de cepas. Rev. Latinoam. Microbiol., 30, 301-305, 1988.

3. Christersson, L.A.; Albini, B.; Zambon, J.J.; Wikesjö, U.M.; Genco R.J. Tissue localization of Actinobacillus actinomycetemcomitans in human periodontitis. I Light immunofluoresce and electron microscopic studies. J. Periodontol., 58, 529-539, 1987.

4. Eley, B.M.; Cox, S.W. Proteolytic and hydrolytic enzymes from putative periodontal pathogens: characterization, molecular genetics, effects on host defenses and tissues and detection in gingival crevice fluid. Periodontol. 2000, 31, 105-124, 2003.

5. Gregory, R.L.; Kim, D.E.; Kindle, J.C.; Hobbs, L.C. Immunoglobulindegrading enzymes in localized juvenile periodontitis. J. Periodont. Res., 27, 176-183, 1992.

6. Hammond, B.F.; Lillard, S.E.; Stevens, R.H. A bacteriocin of Actinobacillus actinomycetemcomitans. Infect. Immun., 55, 686691, 1986.

7. Henderson, B.; Wilson, M.; Sharp, L.; Ward, J.M. Actinobacillus actinomycetemcomitans. J. Med. Microbiol., 51, 1013-1020, 2002.

8. Henderson, B.; Nair, S.P.; Ward, J.M.; Wilson, M. Molecular pathogenicity of the oral opportunistic pathogen Actinobacillus actinomycetemcomitans. Annu. Rev. Microbiol., 57, 29-55, 2003.

9. Lang, N.; Bartold, P.M.; Cullian, M.; Jeffcoa, T.M.; Mombelli, A.; Murakami, S.; Page, R.; Papapanou, P.; Tonetti, M.; Van Dyke, T. Consensus report: Aggressive Periodontitis. Ann. Periodontol., 4, 53, 1999.

10. Lima, F.L.; Farias, F.F.; Campos, P.C.; Totola, A.H.; Tavares, C.A.P.; Costa, J.E.; Farias, L.M.; Carvalho, M.A.R. Leukotoxic activity of
Actinobacillus actinomycetemcomitans isolated from human and non-human primates. Braz. J. Microbiol., 32, 250-256, 2001.

11. Lima, F.L.; Farias, F.F.; Costa, J.E.; Carvalho, M.A.R.; Alviano, C.S.; Farias, L.M. Bacteriocin production by Actinobacillus actinomycetemcomitans isolated from the oral cavity of humans with periodontal disease, periodontally healthy subjects and marmosets. Res. Microbiol., 153, 45-52, 2002.

12. Lowry, O.H.; Rosobrough, M.J.; Farr, A.L.; Randall, R.J. Protein measurement with the Folin phenol reagent. J. Biol. Chem., 246, 1889-94, 1971.

13. Marcotte, H.; Lavoie, M.C. Oral microbial ecology and the role of salivary immunoglobulin A. Microbiol. Mol. Biol. Rev., 62, 71-109, 1998.

14. Page, R.C.; Vandesteen, G.E.; Ebersole, J.L.; Willians, B.L.; Dixon, I.L.; Altman L.C. Clinical and laboratory studies of a family with a high prevalence of juvenile periodontitis. J. Periodontol., 56, 602-609, 1985.

15. Shenker, B.J.; Vitale, L.A.; Welham, D.A. Immune suppression induced by Actinobacillus actinomycetemcomitans: Effects on immunoglobulin production by human B cells. Infect. Immun., 58, 3856-3862, 1990.

16. Smith, D.J.; Taubman, M.A. Immune components in dental plaque. J. Dent. Res., C55: 153-162, 1976.

17. Vale, C.H.B.; Fraga, L.A.O.; Costa, A.S.; Tavares, C.A.P.; MartinsFilho, O.A.; Farias, L.M.; Carvalho, M.A.R. Antiproliferative activity of Actinobacillus (Haemophilus) actinomycetemcomitans and Fusobacterium nucleatum in peripheral blood mononuclear cells. Res. Microbiol., 155, 731-740, 2004.

18. Van-Sttenbergen, T.J.; Bosch-Tijhof, C.J.; Van Winkelhoff, A.J.; Gmür, R.; Graff, J. Comparison of six typing methods for Actinobacillus actinomycetemcomitans. J. Clin. Microbiol., 32, 2769-2774, 1994.

19. Wang, P.L.; Shirasu, S.; Shinohara, M.; Daito, M.; Fujii, T.; Kowashi, Y.; Ohura, K. Purification and characterization of a tripsin- like protease from the culture supernatant of Actinobacillus actinomycetemcomitans Y4. Eur. J. Oral Sci., 107, 147-153, 1999.

20. Zambon, J.J. Actinobacillus actinomycetemcomitans in human periodontal disease. J. Clin. Periodontol., 12, 1-20, 1985. 